\title{
Social media engagement: a model of antecedents and relational outcomes
}

\section{Laurence Dessart}

To cite this article: Laurence Dessart (2017) Social media engagement: a model of antecedents and relational outcomes, Journal of Marketing Management, 33:5-6, 375-399, DOI: 10.1080/0267257X.2017.1302975

To link to this article: http://dx.doi.org/10.1080/0267257X.2017.1302975

$$
\text { 曲 Published online: } 27 \text { Mar } 2017 .
$$

Submit your article to this journal

LIII Article views: 362

Q View related articles $\longleftarrow$

View Crossmark data \lceil 


\title{
Social media engagement: a model of antecedents and relational outcomes
}

\author{
Laurence Dessart \\ Marketing Department, KEDGE Business School, Talence, France
}

\begin{abstract}
This article investigates individual-level antecedents and relational outcomes of social media engagement. Social media engagement approached in this study is a three-dimensional construct composed of affective, cognitive and behavioural dimensions. Surveying more than 48 Facebook pages, spanning nine product categories and 448 consumers, the results show that product involvement, attitude towards the community and online interaction propensity all impact social media engagement. The study also reveals that high social media engagement increases brand relationships significantly, particularly affecting brand trust, commitment and loyalty. Additionally, community engagement appears as a precursor of brand engagement. These findings provide insight into antecedents and outcomes of engagement for academic research and bring value to online brand and community management.
\end{abstract}

\section{ARTICLE HISTORY}

Received 16 September 2016 Accepted 16 February 2017

\section{KEYWORDS}

Social media; consumer engagement; online community; brand relationship

\section{Introduction}

At a time in which companies are increasingly competing for consumer attention, social media afford unique opportunities to engage consumers on deep and meaningful levels. Consumers partake in interactive experiences with brands or community members beyond a simple purchase (Brodie, Ilic, Juric, \& Hollebeek, 2013), creating more enduring and intimate relationships with brands (Sashi, 2012). Given that the global social media user population comprises 2.2 billion people in 2016 and is expected to grow to 3 billion by 2020 (Statista, 2016), strategic consumer insight focusing on social media is essential for brands. This study uses the concept of social media engagement, a potent construct that captures the complexity of social media participation (Dessart, Veloutsou, \& Morgan-Thomas, 2015) to provide such insight.

The role of social media engagement in a nomological network of relationships with other consumer- and brand-related constructs (Hollebeek, Glynn, \& Brodie, 2014) is of interest here. For this reason, the study focuses on understanding specific drivers and outcomes of social media engagement. Understanding the 
reasons why people engage and the results of engagement affects the way companies manage brands and communities online in important ways. Given the paucity of studies investigating on a large scale and in a generalisable manner these relationships (Hollebeek, Conduit, \& Brodie, 2016), this study endeavours to determine some of the key drivers and outcomes of social media engagement.

To date, research into the antecedents and outcomes of social media engagement is high on the agenda of engagement practice and scholarship. This goal is evidenced in recent special issues (e.g. Journal of Marketing Management, 2016) and by the call for dedicated research on how 'social media and other marketing activities create engagement' (MSI, 2014, p. 4). Hollebeek et al. (2016) prove the lack of research in this domain and the existing research's limited scope for generalisability. Specifically, existing studies have restricted contextual scopes (e.g. Vivek, Beatty, \& Morgan, 2012), focus on a small set of variables (e.g. Malthouse Calder, Kim, \& Vandenbosch, 2016), or include too few brands or products (e.g. Hollebeek et al., 2014), calling for an extension of the generalisability of this stream of research (Hollebeek et al., 2016).

Studies exploring the antecedents and outcomes of engagement on social media from the last few years have opened avenues. Theories of regulatory fit, for instance, can help determine engagement types and levels on Facebook (Solem \& Pedersen, 2016), and personality traits of consumers also affect engagement formation (Marbach, Lages, $\&$ Nunan, 2016). Other exploratory work also suggests that consumers engage in online community settings to reduce information search and perceived risk (Brodie et al., 2013). In terms of outcomes, social media engagement is a trigger for buying intentions and decisions (Brodie et al., 2013; Malthouse et al., 2016).

Despite these interesting advances, knowledge is still lacking, specifically on the role of consumer engagement on brand relationship development across contexts (Hollebeek et al., 2016). Much conceptual and exploratory work exists on the role of consumer engagement in brand-relationship formation (Brodie et al., 2013; Hollebeek, 2011b; Van Doorn et al., 2010; Vivek et al., 2012), but this work is still to be validated in social media environments. Understanding the ways in which engagement can transform individual consumer predispositions into beneficial brand outcomes is at the heart of this study.

The purpose of the present study is thus to provide an account of some of the key individual-level antecedents and relational outcomes of social media engagement. Conceptualising social media engagement as a multifocal, multidimensional and context-specific phenomenon, the study proposes individual-level antecedents and anticipates social media engagement to lead to a series of positive brand-relationship outcomes, including brand trust, commitment and loyalty.

This article starts with a literature review conceptualising social media engagement; its dimensions, actors and focus and then reviews existing insights and gaps concerning its antecedents and outcomes. The next section presents the hypotheses, leading to a conceptual model of social media engagement. The methodology covers the practical aspects of data collection and analysis, followed by results and discussions. The last section deals with the practical and theoretical implications of the study. 


\section{Literature review and hypothesis formulation}

\section{Social media engagement}

Consumer or customer engagement scholarship has grown significantly in the last 7 years (Dessart, Veloutsou, \& Morgan-Thomas, 2016; Sprott, Czellar, \& Spangenberg, 2009; Van Doorn et al., 2010). The overall agreement resulting from recent customer engagement research pictures it as a 'psychologically based willingness to invest in the undertaking of focal interactions with particular engagement objects' (Hollebeek et al., 2016, p. 2). Three dimensions constitute engagement: cognitive, affective and behavioural (Calder, Malthouse, \& Schaedel, 2009; Dessart et al., 2015; Hollebeek, 2011a, 2011b). Specifically, Dessart et al. (2015, 2016) conceptualise cognitive engagement similar to the overall mental activity focused on something, involving attention and absorption. Affective engagement is composed of enthusiasm and enjoyment with regard to an engagement object. Last, behavioural engagement represents the active manifestations of the concept, including sharing, learning and endorsing behaviours.

Social media engagement is a context-specific occurrence of consumer engagement (Brodie et al., 2013) worth considering since engagement varies across online media (Geissinger \& Laurell, 2016). Social media are vast ecosystems with intricate networks of relationships and a multiplicity of social nets and levels of interactions. Scholars define them as 'a group of Internet-based applications that build on the ideological and technological foundations of Web 2.0, and allow the creation and exchange of User Generated Content' (Kaplan \& Haenlein, 2010, p. 61). Social media include social networking sites such as Facebook or Instagram, but also other media like YouTube, Flickr or blogs. The important feature of social media when it comes to consumer engagement is that they allow consumer-brand interactions. Specifically, when a brand is present on social media and uses it to connect with its consumers, an online brand community is formed (Zaglia, 2013). Given the consumer-brand interactions that social media allow, this study focuses on online brand communities embedded on social media as the context of engagement (Brodie et al., 2013; Zaglia, 2013).

This focus follows work by Breidbach, Brodie, and Hollebeek (2014), which pinpoints the importance to model and study engagement with respect to specific consumer touchpoints. Furthermore, social media enable 'more frequent, faster and richer interactions among large groups of people' (Sashi, 2012, p. 269). One way of fostering these rich interactions on social media is the use of online brand communities, which are powerful tools in consumer relationship strategies and are at the forefront of academic and industry studies (Forrester Research, 2014).

In this context of online brand communities embedded on social media, this study defines social media engagement as the state that reflects consumers' positive individual dispositions towards the community and the focal brand as expressed through varying levels of affective, cognitive and behavioural manifestations that go beyond exchange situations. This study focuses on the positive facet of engagement experiences. Although acknowledging the existence and importance of negatively valenced engagement (Hollebeek \& Chen, 2014), this article focuses on positive engagement and its positive outcomes to extend existing work in this domain (Brodie et al., 2013). 
A focus on positive engagement is adopted in this article for several reasons. First, the treatment of negative engagement would necessitate a different method based on the status of extant research negative engagement research. Indeed, the field still embryonic and mostly restricted to conceptualisation and exploratory work (Hollebeek \& Chen, 2014), whereas positive engagement research already benefits from stronger empirical ground, allowing to contribute to the development of existing frames and models (e.g. Dessart et al., 2015, 2016; Marbach et al., 2016) in a confirmatory manner. Further, negative engagement seems driven by other antecedents than positive engagement (Dolan, Conduit, Fahy, \& Goodman, 2016). Specifically, brand-related motives are prominent in the development of negative engagement (Hollebeek \& Chen, 2014) whereas individual predispositions are not recognised as relevant to study. The article also uses the term 'consumers', rather than 'customers', considering that social media users are 'consumers' of the platform, without having to be 'customers' of any brand to engage on the platform.

An important aspect of this definition is the duality of engagement objects: the community and the brand. On social media, engagement can emerge with respect to different objects (Wirtz et al., 2013). Algesheimer, Dholakia, and Herrmann (2005) are precursors of this idea with their study on community engagement in offline brand communities. In online and social media ecosystems, many recent studies parallel this notion of community engagement (Wirtz et al., 2013). Brand engagement, on the other hand, is probably the most studied engagement focus (Van Doorn et al., 2010; Verhoef, Reinartz, \& Krafft, 2010), including in social media contexts (Malthouse et al., 2016; Marbach et al., 2016). In this study, the view is that, in online brand communities embedded on social media, the two key engagement objects are the community, representing the other consumers in the group, and the focal brand (Brodie et al., 2013; Dessart et al., 2015, 2016). In order to clarify the concept of social media engagement, Table 1 provides examples of manifestations of consumer engagement on social media for each of its dimensions and foci.

Social media engagement comprises community engagement and brand engagement, and therefore understanding how these two focuses of engagement coexist becomes important (Brodie et al., 2013). Their specific dynamic might in fact contribute to the creation, sustenance and vitality of the communities and affect customer relationships and brand management strategies (Hennig-Thurau et al., 2010). Despite a lack of research on the interplay between community engagement

Table 1. Example of social media engagement manifestations.

\begin{tabular}{lll}
$\begin{array}{l}\text { Dimension } \\
\text { of engagement }\end{array}$ & \multicolumn{1}{c}{ Brand focus } & \multicolumn{1}{c}{ Community focus } \\
\hline Affective & $\begin{array}{c}\text { A consumer feeling happy that a brand has } \\
\text { replied to his question on social media }\end{array}$ & $\begin{array}{c}\text { A consumer enjoying interacting with other fans } \\
\text { of a brand on social media }\end{array}$ \\
$\begin{array}{l}\text { A consumer who is so absorbed in the content } \\
\text { posted by the brand on social media that he } \\
\text { spends a lot of time browsing it }\end{array}$ & $\begin{array}{c}\text { A consumer paying a lot of attention to the } \\
\text { comments and replies of other consumers } \\
\text { about the brand on social media }\end{array}$ \\
Behavioural & A consumer sharing his opinion about a product \\
with the brand on social media & $\begin{array}{c}\text { A consumer seeking information about the } \\
\text { brand and asking other members of the } \\
\text { community for their help or advice on social } \\
\text { media }\end{array}$ \\
\hline
\end{tabular}


and brand engagement (Dessart et al., 2015, 2016), conceptual studies suggest that community engagement leads to increased levels of brand engagement (Wirtz et al., 2013). This observation is in line with other community studies that prove the positive impact of community practices on brand engagement (Schau, Muñiz, \& Arnould, 2009), supporting the development of the first hypothesis:

Hypothesis 1: Community engagement positively influences brand engagement.

\section{Antecedents and outcomes}

Appendix 1 gives an account of all consumer engagement research that has investigated its antecedents and outcomes. The table shows that until 2013, most studies have been conceptual (e.g. Bowden, 2009; Van Doorn et al., 2010) and none has a specific social media or online focus. This stream of research, however, shows a vast interest in the impact of consumer engagement on brand relationship constructs, such as trust, commitment, satisfaction or loyalty (Bowden, 2009; Brodie, Hollebeek, Juric, \& Ilic, 2011; Hollebeek, 2011a, 2011b), or brand recall and attention (Sprott et al., 2009). Other conceptual antecedents of engagement include several individual variables, such as identity or consumption goals (Van Doorn et al., 2010) or interactivity and involvement (Hollebeek, 2011b; Sprott et al., 2009), for instance.

Since 2013, scholars have tackled the scarcity of empirical research on the drivers and outcomes of engagement, particularly in Brodie et al. (2013), who propose antecedents and outcomes of online brand community engagement on the basis of qualitative data. More recent studies advance this research by finding empirical evidence on social media that engagement leads to brand love or word of mouth (WOM) and that this engagement is driven by specific personality traits (Marbach et al., 2016). Apart from Brodie et al. (2013), studies focusing on consumer engagement on social media and its drivers and outcomes are scarce, to say the least. This lack of interest in social media engagement represents an important oversight of the engagement literature, also leading to a limited account of the potential community engagement outcomes and antecedents (Brodie et al., 2013). However, existing studies provide a guidance to develop hypotheses.

In line with past studies highlighting the importance of individual factors in driving engagement (France, Merrilees, \& Miller, 2016; Marbach et al., 2016; Solem \& Pedersen, 2016; Vivek et al., 2012), this article focuses on three variables that capture individual predispositions: online interaction propensity (OIP), attitude towards community participation and product involvement. These variables were chosen because they align with the notion that engagement results from intrinsic motivational triggers (Brodie et al., 2011).

In communication and psychology disciplines, OIP means the willingness to communicate with others, and people can exhibit different levels of propensities to interact (Wiertz \& De Ruyter, 2007). OIP is a fairly under-researched individual trait in the formation of online brand community participation. Blazevic, Wiertz, Cotte, De Ruyter, and Keeling (2014) determine that general online social interaction propensity is an explanatory factor for consumer engagement and online interaction behaviours, 
confirming its anticipated impact on social media engagement, thus leading to the second hypothesis:

Hypothesis 2: Online interaction propensity is positively related to social media engagement as defined by a composition of (a) community engagement and (b) brand engagement.

Despite a lack of focus on attitude in existing consumer engagement frameworks, past scholarship on online consumer behaviours shows the importance of the attitudes, particularly using the theory of planned behaviour (TPB) (e.g. Bagozzi \& Dholakia, 2006). Following Wu and Chen (2005), the attitude towards online community participation reflects in this study the favourable or unfavourable assessment a consumer makes of participating in the community. In an extended version of the TPB, Bagozzi and Dholakia (2006) find that attitude towards brand community participation is a driver of the desire, intention and behaviour of community participation. Similarly, Casaló, Flavián, and Guinalíu (2010) show that member attitude towards participation in a firm-hosted online travel community is a potent driver of the actual intention to participate. These findings find further conceptual validation in Hennig-Thurau et al. (2010), who assert that consumers with high positive attitudes towards new media are more likely to exhibit high levels of new media brand engagement. The following hypothesis reflects this expected contribution of attitude towards engagement:

Hypothesis 3: Attitude towards community participation is positively related to social media engagement as defined by a composition of (a) community engagement and (b) brand engagement.

A last important potential antecedent of social media engagement is involvement (Hollebeek, 2011b; Sprott et al., 2009; Vivek et al., 2012), but this relationship has received little empirical attention (Hollebeek et al., 2014). Studying involvement is important because whether a product generates high or low involvement could significantly affect consumer engagement with the product (Hollebeek, 2011a). Although involvement and engagement might seem similar, involvement does not have a behavioural aspect. In fact, Hollebeek et al. (2014) prove the empirical distinctiveness of engagement and involvement, further validating the mediating role of engagement in the relationship between involvement and self-brand connection. Product involvement overall seems to be a powerful antecedent of social media engagement, leading to the fourth hypothesis:

Hypothesis 4: Product involvement is positively related to social media engagement as defined by a composition of (a) community engagement and (b) brand engagement.

The potential outcomes of social media engagement fall under the brand relationship framework. Indeed, consumer engagement frames the next generation of brand 
relationships and offers an extended version of previous relational models (Vivek, Beatty, Dalela \& Morgan, 2014). Appendix 1 proves in particular the strong appetency of engagement scholarship for relational metrics. Additionally, online community-based research also stresses the role of online communities in sustaining consumer-brand relationships (e.g. Matzler, Pichler, Füller, \& Mooradian, 2011).

Brand trust and brand commitment are two closely related constructs in foundational brand relationship research (Chaudhuri \& Holbrook, 2002) and in recent consumer engagement studies (Hollebeek, 2011b). In this study, brand trust is the willingness of the consumer to rely on the ability of the brand to perform its stated function (Moorman, Zaltman, \& Deshpande, 1992), and brand commitment is the enduring desire to maintain a valued relationship with a brand in the long term (Morgan \& Hunt, 1994). Brand commitment is based on the emotional or psychological attachment to and preference for a brand within a product category (Lastovicka \& Gardner, 1979). According to Gambetti and Graffigna (2010), engagement, in the relational sense of the term, is a way to build trust and commitment with the brand. More recently, Hollebeek et al. (2014) showed the impact of engaging with social media brands (such as Facebook or Linkedln) on self-brand connection and brand usage intent. Combined with the conceptual work positing brand trust and brand commitment as outcomes of brand engagement in social media contexts (Brodie et al., 2013), the fifth hypothesis reads as follows.

Hypothesis 5: Brand engagement is positively related to (a) brand trust and (b) brand commitment.

In social media and online community studies, behavioural brand loyalty is a common dependent variable and success factor of the community (e.g. Algesheimer et al., 2005; Bagozzi \& Dholakia, 2006), thus requiring further attention in an engagement framework. Similarly, in traditional relationship marketing, the impact of brand commitment and brand trust on brand loyalty is well verified (e.g. Garbarino \& Johnson, 1999), as well as in brand community contexts (Marzocchi, Morandin, \& Bergami, 2013; Porter \& Donthu, 2008). Conceptually, trust and commitment also have a mediating role in driving loyalty from engagement (Hollebeek, 2011b), supporting the need for empirical validation of this relationship. Aligning early relationship marketing studies with community and consumer engagement research enables positing that, with the precedence of consumer engagement over brand trust and commitment, the following hypotheses hold for social media engagement:

Hypothesis 6: Brand trust is positively related to brand loyalty.

Hypothesis 7: Brand commitment is positively related to brand loyalty.

Figure 1 summarises the hypotheses. 


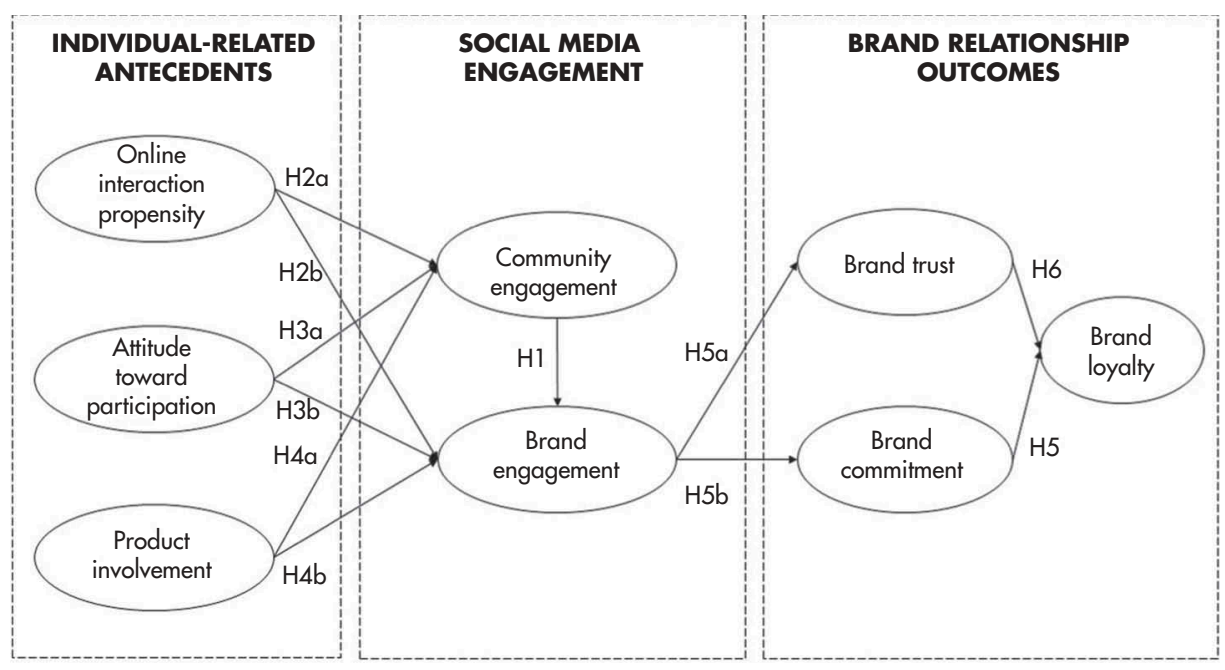

Figure 1. The conceptual model.

\section{Method}

Official brand pages on Facebook serve as the context of this study for several reasons. Facebook is the biggest global social media in terms of usage, with more than 1 billion registered users and 1.59 billion monthly active users (Statista, 2016). Additionally, Facebook is a powerful tool for brand relationships creation: users can share their enthusiasm about the brand and are united by their common interest in the brand (Malhotra, Malhotra, \& See, 2012). Facebook pages are also sources of information and social benefits to the members (De Vries, Gensler, \& Leeflang, 2012). Recent focus on Facebook in the context of consumer engagement further supports the adequacy of Facebook as an engagement medium (Solem \& Pedersen, 2016). Additionally, Facebook is a rich platform for brands and supports a large variety of brand pages, depending on the type of product and business.

A first level of purposive sampling is applied in the selection of Facebook pages (30 million Facebook pages exist at the time of the study) to categorise the type of pages under investigation. The aim of this categorisation is to make sure each type of Facebook page is represented, thus using Facebook's own classification criteria, as well as Social Bakers (2014) to come up with a selection of nine brand page categories: (1) food and beverage, (2) travel, (3) fashion and beauty, (4) entertainment, (5) durable goods, (6) services, (7) technology, (8) retail and (9) others. The research does not attempt statistical representativeness of the number of existing Facebook pages. Rather, a good span of all pages in terms of product types seeks to extend the validity of previous engagement studies, which often focus on service brands (e.g. Jaakkola \& Alexander, 2014).

The questionnaire displays multiple-choice, 7-point Likert scale questions, capturing constructs of interest with existing scales. Bagozzi and Dholakia's (2006) scale measures attitude towards community participation; Laurent and Kapferer's (1985) research measures product involvement; Wiertz and de Ruyter's (2007) scale 
measures OIP; Chaudhuri and Holbrook's (2001) research measures brand trust; ElManstrly and Harrison's (2013) research operationalises brand commitment; Odin, Odin, and Valette-Florence's (2001) research measures brand loyalty and Dessart et al.'s (2016) scale determines social media engagement, composed of community and brand engagement. This latter scale was chosen as a measure of social media engagement in opposition to other recent engagement scales (e.g. Hollebeek et al., 2014; Vivek et al., 2014) because it is the one that best allows capturing the dual engagement focus on the brand and the community, and reflects the conceptual position on dimensionality. Furthermore, it allows measuring the enduring and ongoing nature of engagement, in contrast to Hollebeek et al. (2014), which is interaction-bound. Dessart et al. (2016) also provides a better operationalisation of the social media engagement concept and its dimensionality than Vivek et al. (2014), who pool together the emotional and participative dimensions into one. The detail of the items used in this study is provided in Appendix 2.

Prior to full-scale collection, the survey is pretested on a sample of 101 undergraduate and postgraduate business students, enabling the research to validate the good understanding of the questions, the appropriateness of their wording and sequencing, and offer a first check of the internal consistency, means, variances, inter-item correlations and factor structure.

Data are collected by contacting brand page administrators and asking them to post the link to the survey on their page. This approach ensures that the study is done with respect to the chosen brands and brand categories and that respondents to the survey are indeed members of these communities. This match would not have been possible by contacting people through other channels. Prior brand page experience is a prerequisite to having the required level of knowledge and memory to answer the questionnaire. Additionally, the fact that the post is written by the administrator increases the source credibility of the survey and builds trust for respondents, which is important in the study of community members who are hard to reach. Over a period of 5 months, researchers contacted a total of 326 page administrators, with 48 of them posting the survey on their page, resulting in a posting rate of $15 \%$. When clicking on the link, respondents are redirected to the web-based questionnaire.

A total sample size of 448 respondents constitutes the final sample. The respondents' age ranges between 18 and 82 years old with a median of 29, and the study consists of $51 \%$ female. Respondents come from a total of 75 different countries, out of which the United Kingdom and the United States are most represented. In terms of brand categories, food and beverage achieve the highest overall score (33\%), followed by travel (21\%), fashion and beauty $(14 \%)$, and entertainment (12\%). These brand categories match Facebook's current bestperforming categories. Roughly $83 \%$ of the respondents are purchasing clients of the brand they follow, evidencing that online brand use and membership does not imply prior buying behaviour. Respondents exhibit relatively high levels of Facebook activity because close to $30 \%$ of them spend 60 min or more on Facebook every day. The complete detail of sample characteristics and brand pages surveyed can be found in Appendices 3 and 4. 


\section{Results}

The analysis uses a two-phase structural equation modelling (SEM) process, focusing first on the measurement model to assess the factor structure and then looking at the structural model to test the hypothesised links between the variables and assess the fit of the full structural model with the data (Anderson \& Gerbing, 1988).

\section{Reliability and validity}

Establishing the reliability and validity of the scales is essential before testing the model. The constructs are internally consistent with all Cronbach's alpha values above 0.86 (Bagozzi \& Yi, 1988). The convergent validity indicators are also satisfactory, with average variance extracted (AVE) values all above 0.61 , supporting the measurement model's convergent validity. The coefficient of reliability (CR) indicators are equal to or above 0.83 for all constructs, which further indicate reliability, as Hair, Bush, and Ortinau (2006) suggest. Correlations among latent variables are all significant ( $C R \geq 1.96)$. All AVEs are superior to the square of their related pairwise correlations, which also indicates that the measurement model achieves discriminant validity, as shown in Table 2. As expected due to their conceptual similarity, community engagement and brand engagement show a high pairwise correlation (0.89). This figure is, however, not problematic since it shows good construct validity (Bagozzi, Yi, \& Phillips, 1991), and supports the fact that they measure the same construct, albeit for a different engagement focus. Further, a full Fornell-Larcker test was computed, and the maximum shared variances and average shared variances for all variables are smaller than their AVEs, thus ensuring complete discriminant validity.

\section{Model analysis}

The measurement model exhibits a chi-square of $1741.34(p=0.00)$ with 1535 degrees of freedom, comparative fit index (CFI) $=0.84$, Tucker Lewis Index $(T L I)=0.83$ and an root mean square residuals (RMSEA) $=0.06$. All standardised loadings are above or close to 0.50 and $t$-values are all significant $(p<0.01)$. The reasons for CFI and TLI measures below the advocated guidelines are largely because of the nature of the engagement scales included in the model, because lengthy and complex scales are more difficult to

Table 2. Reliability and validity.

\begin{tabular}{lcccccccc}
\hline Constructs & 1 & 2 & 3 & 4 & 5 & 6 & 7 & 8 \\
\hline 1. Brand engagement & $\mathbf{0 . 8 4}$ & 0.79 & 0.32 & 0.47 & 0.43 & 0.25 & 0.33 & 0.15 \\
2. Community engagement & 0.89 & $\mathbf{0 . 8 6}$ & 0.21 & 0.24 & 0.20 & 0.13 & 0.29 & 0.22 \\
3. Brand loyalty & 0.56 & 0.46 & $\mathbf{0 . 6 1}$ & 0.30 & 0.43 & 0.17 & 0.17 & 0.05 \\
4. Brand trust & 0.69 & 0.49 & 0.55 & $\mathbf{0 . 7 4}$ & 0.67 & 0.16 & 0.28 & 0.11 \\
5. Brand commitment & 0.66 & 0.44 & 0.66 & 0.82 & $\mathbf{0 . 7 5}$ & 0.12 & 0.16 & 0.07 \\
6. Product involvement & 0.50 & 0.36 & 0.42 & 0.40 & 0.34 & $\mathbf{0 . 8 9}$ & 0.22 & 0.02 \\
7. Attitude & 0.58 & 0.54 & 0.41 & 0.53 & 0.40 & 0.46 & $\mathbf{0 . 7 4}$ & 0.05 \\
8. OIP & 0.39 & 0.47 & 0.22 & 0.33 & 0.26 & 0.14 & 0.23 & $\mathbf{0 . 7 8}$ \\
CR & 0.94 & 0.95 & 0.86 & 0.86 & 0.90 & 0.94 & 0.92 & 0.93 \\
Alpha & 0.90 & 0.93 & 0.86 & 0.91 & 0.90 & 0.94 & 0.91 & 0.93 \\
\hline
\end{tabular}

Note: The diagonal (values given in bold) represents the AVEs of each construct; below the diagonal are the pairwise correlations between constructs and above are the squared pairwise correlations. 
use in models with many variables and may result in redundancy between closely related items (Ruvio, Shoham, \& Brencic, 2008). It is the case here because engagement is measured for two different engagement objects. However, the constructs perform perfectly at their higher-order levels, showing no evidence of multicollinearity, and the engagement scale is valid (Dessart et al., 2016).

\section{Hypothesis testing}

Hypothesis testing uses SEM with maximum likelihood estimation. In the causal path model, the statistics support that the data fit the model at adequate levels with a significant chi-square $=3441.881(p=0.00)$ with 1066 degrees of freedom. The CFI is $0.89, \mathrm{TLI}$ is 0.90 and RMSEA equals 0.06 . The study discusses the acceptable support for model fit prior to the SEM measurement model results.

Most of the hypothesised relationships hold according to the path analysis, with different yet largely consistent estimates for each sample. More specifically, $\mathrm{H} 1$ and $\mathrm{H} 2 \mathrm{~b}$ fail to account for the impact of OIP and attitude towards community engagement on online brand engagement. Additionally, the data fail to support $\mathrm{H} 7$, evidencing rejection of the impact of brand trust on brand loyalty.

The significance of the model's path coefficient shows that online brand engagement is positively influenced by product involvement $(\beta=0.20$, sig $=0.00)$ and community engagement $(\beta=0.75$, sig $=0.00)$, showing support for $\mathrm{H}_{1}$ and $\mathrm{H}_{4 \mathrm{~b}} \cdot \mathrm{H}_{2 \mathrm{~b}}(\beta=-0.20$, sig $=0.69)$ and $\mathrm{H}_{3 \mathrm{~b}}(\beta=0.09 \mathrm{sig}=0.07)$, however, are not supported. OIP and attitude towards community participation therefore have no effect on online brand engagement. The results also show that the most powerful predictor of brand engagement is by far community engagement $(\beta=0.75)$, with an overall $R^{2}$ of 0.73 for brand engagement.

All the hypotheses related to the drivers of community engagement exhibit significant values. Support is therefore granted to $\mathrm{H}_{2 a}(\beta=0.39$, sig $=0.00), \mathrm{H}_{3 a}$ $(\beta=0.47$, sig $=0.00)$ and $\mathrm{H}_{4 \mathrm{a}}(\beta=0.18$, sig $=0.00)$. This result shows that community engagement is significantly and positively influenced by consumer's OIP, attitude towards community participation and product involvement. Data show that the strongest influence of community engagement derives from consumer's general attitude towards online participation $(\beta=0.47$, sig $=0.00)$, directly followed by OIP $(\beta=0.39$, sig $=0.00)$, with an $R^{2}$ of 0.40 .

Brand trust is positively influenced by brand engagement, supporting $\mathrm{H}_{5 \mathrm{a}}(\beta=0.72$, sig $=0.00)$, and $\mathrm{H}_{5 \mathrm{~b}}$ is also validated, as evidenced by the significant beta values $(\beta=0.69$, sig $=0.00)$. Brand engagement therefore affects brand trust and brand commitment, with a stronger influence on brand trust. Last, the impact of brand trust and brand commitment on brand loyalty is hypothesised, respectively, with $\mathrm{H}_{6}$ and $\mathrm{H}_{7}$. The data show rejection of $\mathrm{H}_{6}(\beta=0.09$, sig $=0.19)$. The impact of brand commitment on brand loyalty is supported, denoting acceptance of $\mathrm{H}_{7}(\beta=0.60$, sig $=0.00)$, with an $R^{2}$ for brand loyalty of 0.42 . Table 3 summarises the hypotheses' support.

\section{Alternative model}

An alternative model whereby brand commitment and brand trust are hypothesised to be antecedents of consumer engagement rather than outcomes is thus run, since the 
Table 3. Hypothesis testing.

\begin{tabular}{|c|c|c|c|c|}
\hline Hypothesis & Path & $\beta$ & $\mathrm{CR}$ & Hypothesis support \\
\hline $\mathrm{H} 1$ & Community engagement $->$ brand engagement & $0.75^{* *}$ & 9.75 & Supported \\
\hline $\mathrm{H} 2 \mathrm{~b}$ & Online interaction propensity $->$ brand engagement & -0.2 & -0.39 & Not supported \\
\hline $\mathrm{H} 3 \mathrm{~b}$ & Attitude towards community $->$ brand engagement & 0.09 & 1.78 & Not supported \\
\hline $\mathrm{H} 4 \mathrm{~b}$ & Product involvement $->$ brand engagement & $0.20^{* *}$ & 4.19 & Supported \\
\hline $\mathrm{H} 2 \mathrm{a}$ & Online interaction propensity $->$ community engagement & $0.39 * *$ & 6.41 & Supported \\
\hline $\mathrm{H} 3 \mathrm{a}$ & Attitude towards community $->$ community engagement & $0.47^{* *}$ & 7.49 & Supported \\
\hline $\mathrm{H} 4 \mathrm{a}$ & Product involvement $->$ community engagement & $0.18^{*}$ & 3.03 & Supported \\
\hline $\mathrm{H} 5 \mathrm{a}$ & Brand engagement $->$ brand trust & $0.72^{* *}$ & 10.50 & Supported \\
\hline $\mathrm{H} 5 \mathrm{~b}$ & Brand engagement $->$ brand commitment & $0.69^{* *}$ & 9.39 & Supported \\
\hline $\mathrm{H} 6$ & Brand trust $->$ brand loyalty & 0.09 & 1.28 & Not supported \\
\hline $\mathrm{H} 7$ & Brand commitment $->$ brand loyalty & $0.60^{* *}$ & 6.80 & Supported \\
\hline
\end{tabular}

*Significant at the 0.05 level.

**Significant at the 0.01 level.

direction of the relationship, as we hypothesise it, has been conceptually challenged (Hollebeek, 2011a) The same statistical techniques as previously detailed are used. In this alternative model, social media engagement is not significantly impacted by brand trust and brand commitment ( $\beta$ are all below 0.14 and significance levels above 0.05). Brand relational variables can therefore not be modelled as antecedents of online brand community $(\mathrm{OBC})$ engagement. Goodness of fit values of the alternative model support this assertion with: chi-square $=2705.92(p=0.00)$ with 685 degrees of freedom. The CFI is $0.74, \mathrm{TLI}$ is 0.76 and RMSEA equals 0.11 . The testing of the alternative model shows that brand trust and commitment should definitely not be modelled as antecedents of OBC engagement, and that trust and commitment are also better modelled as outcomes of online brand engagement. In other words, the testing of the alternative model further validates the adequacy of this study's model.

\section{Discussion}

The results of the hypothesis testing provide important insights into the antecedents and outcomes of social media engagement, as well as the link between engagements with two focal objects in social media settings. Importantly, the interplay between the two aspects of social media engagement addressed in $\mathrm{H} 1$ is interesting because it shows that community engagement is the strongest predictor of brand engagement, highlighting the vital explanatory power of community participation over brand engagement (Wirtz et al., 2013). This realisation echoes research in online brand communities whereby interactions with a community of consumers foster stronger and more frequent brand-related behaviours and attitudes (e.g. Algesheimer et al., 2005), also suggesting that the community has a central role in providing brandrelated information, thus increasing brand-related experiences and practice (Calder et al., 2009; Schau et al., 2009). Through community engagement, one's level of brand engagement is triggered and enhanced.

Brand engagement, however, is not directly affected by individual dispositions, other than product involvement. There may be multiple reasons why OIP and attitude towards community participation do not impact brand engagement. Despite being used to online interactions and having a general positive attitude towards it, OBC users might feel that engaging with the brand in public setting is inadequate, preferring to keep 
direct brand interactions in the private sphere. Indeed, consumers are often conscious of what others will think if they interact with brands too closely (Patterson, 2012), thus relating to issues of self-presentation (Hollenbeck \& Kaikati, 2012). This could also be due to online privacy concerns (Murphy, Hill, \& Dean, 2014) such as fear of the brand using these interactions for commercial purposes in the future. Research also shows that when a community becomes too big, people feel hindered in their interactions with brands (Dholakia, Bagozzi, \& Pearo, 2004). This factor was not accounted for in this study but could be a moderator of the relationships in $\mathrm{H} 2 \mathrm{~b}$ and $\mathrm{H} 3 \mathrm{~b}$. On the other hand, involvement with a product is in multiple conceptual and exploratory settings an important driver of brand engagement offline (Dwivedi, 2015; France et al., 2016), and this study proves that this observation is also valid in online social media settings.

Interestingly, although brand engagement on social media cannot be rely heavily on individual predispositions, it can emerge if social stimuli exist in the form of community engagement. The support of $\mathrm{H} 1$ in this study is a reminder of the crucial role of the community of users on social media in generating consumer-brand interactions (Ashley \& Tuten, 2015). Specifically, consumers might not want to interact with brands directly without the intermediation of the community (Fournier \& Avery, 2011). This study suggests that if consumers are involved emotionally, cognitively and behaviourally with other consumers, identical forms of engagement with the brand are more likely to ensue. This echoes existing brand community research showing that by being more exposed to brand-related information and gaining increased brand-related experiences and practice through community engagement (Calder et al., 2009; Schau et al., 2009), one's level of brand engagement is triggered and enhanced. Overall, the findings support that social media represent unique contexts of engagement with unique features (Brodie et al., 2013) and thus necessitate dedicated treatment (Dessart et al., 2015, 2016).

Regarding the drivers of community engagement, this study advances the understanding that individuals on social media exhibit different engagement levels based on their own internal predispositions (France et al., 2016). Specifically, individual factors of attitude, involvement and interaction propensity influence engagement with the community (Blazevic et al., 2014). These variables not only affect consumers' behavioural participation on social media but also the whole engagement manifestations of affect, cognition and behaviours towards other community members. The findings grant further support to the work of De Villiers (2015) and also imply that community engagement on social media is a function of individual traits and predispositions, a postulate that so far has been only conceptual (Wirtz et al., 2013). The findings also support the relevance of considering consumer individual profiles and identity traits in community engagement strategies (Solem \& Pedersen, 2016).

Considering the outcomes, brand engagement affects trust and commitment to the brand. Trust is likely to be increased by engagement because, in the interactive process of engagement, consumers give brands the opportunity to ensure themselves of their quality as a relationship partner (Hollebeek, 2011b). Similar to trust, engagement grows over the long term and repeat occurrences, and if a brand behaves in a way to enable consumers to satisfactorily engage with them, trust is likely to occur. Echoing the recent brand community and social media literature, if the brands provide compelling content to share and learn from, they entertain and keep consumer's attention through their 
actions on social media (Malhotra et al., 2012), enabling consumers to be engaged with them, and if they do so consistently over time, consumers are more likely to trust them (Marzocchi et al., 2013). Similarly, consumers are more likely to develop high commitment, that is to say, a desire to maintain the relationship with the brand (Jang, Olfman, Ko, Koh, \& Kim, 2008). The findings of this study thus suggest that brand engagement is conducive towards brand trust and brand commitment, which are two core aspects of brand relationship quality. So far, these relationships have been only conceptualised (Brodie et al., 2011; Hollebeek, 2011b; Van Doorn et al., 2010).

Finally, the impact of trust and commitment on loyalty is explored in this context. Supporting extensive brand relationship literature (Garbarino \& Johnson, 1999) and brand community literature (Algesheimer et al., 2005; Jang et al., 2008), the findings expand the view that commitment is driving brand loyalty outcomes in social media engagement contexts. However, the relationship between brand trust and brand loyalty is not supported. This interesting finding might be because of the concept of uncertainty avoidance (Hofstede, 2014), which is akin to trust. Indeed, uncertainty avoidance is low in Anglo-Saxon cultures, which represent most of the respondents of the study and can explain why trust is not an important antecedent of loyalty (ElManstrly \& Harrisson, 2013). Additionally, there might be lower trust levels in social media environments, where brands still sometimes tend to be considered as manipulative intruders (Fournier \& Avery, 2011).

\section{Conclusion}

\section{Theoretical contribution}

This study significantly contributes to the identification and validation of antecedents and outcomes of social media engagement. It develops and tests a causal model explaining the role of individual traits and predispositions driving social media engagement and its impact on consumer-brand relationships, answering the call for empirical research into the drivers and outcomes of consumer engagement (Hollebeek et al., 2016). Specifically, the findings bring clarity to the individual traits and predispositions that trigger consumer engagement in social media and proves its benefits for brand relationship building (Vivek et al., 2012).

The consideration of social media engagement as a multifocal phenomenon and the focus on community and brand engagement brings a unique particularity to the study. The article shows that in a given context, when different engagement foci are isolated, the sequence in which they develop is crucial for the overall vitality of engagement. There is evidence that individual consumer traits and characteristics will likely lead to increased levels of community engagement, which then acts as the leading antecedent of brand engagement. Eventually, it is the brand engagement and not community engagement that bring benefits to the brand, though. Engagement with different entities thus responds to different norms, conditions and motivations. They develop in a sequence in social media environments and they are all essential for brands.

Further, this article extends the generalisability of past studies, first by focusing on online environments for the study of antecedents and outcomes, which to date mainly have been considered in offline settings. Second, the study includes nine different product categories 
of data, which goes much further than most studies that usually investigate one or a few brands at most (e.g. Hollebeek et al., 2014). These findings have potent implications for the management of social media online communities and suggest that researchers can replicate broadly similar consumer engagement strategies across brand categories.

\section{Managerial implications}

From a managerial standpoint, the findings shed light on recent advances regarding social media branding strategies and Facebook page management in particular. Malhotra et al. (2012) suggest that in order to increase levels of behavioural engagement on Facebook, brands should not hesitate to heavily promote the brand and its products and directly engage with consumers with calls to action. Although these strategies should prove very powerful in creating brand engagement, this study brings a nuance to their analysis by suggesting that a sequence or progression from community engaging content should create movement to more brand-focused content. In this spirit, researchers should consider the suggestion to post topical content that is not related to the brand during the early stages of community building.

Additionally, the study demonstrates the importance of individual traits in segmenting consumers for effective engagement. For instance, highly informational and educational content is likely to suit more very involved consumers, whereas playful and socially stimulating content would better suit consumers with high online interactivity propensity. Given the multidimensionality of social media engagement, community managers would do well to adopt a very complete engagement strategy, triggering emotional, cognitive and behavioural aspects of engagement to maximise return on social media investment.

\section{Limitations and suggestions for future research}

Despite the valuable contributions that this study brings to the consumer engagement and social media literature, the current examination is not without limitations. First, the cross-sectional nature of the data does not enable understanding the evolution of engagement through time. Several authors suggest that engagement is an ongoing process of cyclical nature (e.g. Bowden, 2009), and measuring engagement at several points in time should enhance the understanding of this enduring phenomenon. Additionally, qualitative or organic netnographic data could be useful in furthering the understanding of the motivations for engaging on social media. This type of data could also shed light on the under-researched construct of negative engagement on social media (Dolan et al., 2016) and advance the understanding of the whole spectrum of engagement valence. While a die-hard brand fan is unlikely to ever engage negatively, most consumers can move on the continuum of positive-negative engagement in official brand outlets (Hollebeek \& Chen, 2014) and some even join anti-brand movements characterised by strong levels of negative engagement (Dolan et al., 2016).

One of the most interesting findings of this study lie in the unique link between community and brand engagement, and it opens avenue to further investigation of multifocal engagement situations. For instance, it would be worth testing whether this relationship holds in other environments and conditions (other consumer-brand touchpoints or media) or if the direction of the relationship is ever reversed or impacted 
by media-specific functionalities. Further, since engagement with each focus is multidimensional, it would be interesting to test the interplay of cognitive, affective and behavioural dimensions of community and brand engagement. It might be the case that behavioural brand engagement depends mainly on affective community engagement, for instance, as recent studies suggest that behavioural engagement can follows a hierarchical sequence (Schivinski, Christodoulides, \& Dabrowski, 2016). Future work on the interplay and interdependence of the dimensions of community and brand engagement is required.

Researchers should also investigate other antecedents and outcomes of engagement. This study includes some of the most relevant and cited variables related to engagement, but many are left to explore (Mollen \& Wilson, 2010). Antecedents could include perceived costs and benefits of engaging (Van Doorn et al., 2010) while outcomes could focus on brand recall and attention (Sprott et al., 2009) or brand experiences (Hollebeek, 2011a). Further, social media engagement is by nature bound to social media environments and touchpoints, which only represent one portion of all omni-channel consumer-brand interactions, and only one facet of the vast engagement ecosystem (Breidbach et al., 2014). As consumers interact with brands through ever increasing amounts of touchpoints (Lemon \& Verhoef, 2016), social media engagement is limited in scope and might be impacted by engagement through other channels. Further, our sample is highly educated, with almost $50 \%$ of the sample having a postgraduate degree, and education level might not be foreign to the causal effect tested in this study, particularly when it comes to cognitive engagement. The role of such confounding engagement variables should be included in further research to expand on the tested model. Last, researchers should undertake additional efforts to enhance the generalisability of the findings: social media are continuously evolving and expanding, and engagement research on other platforms could lead to other results. New developments in the attention economy have seen the rise of social media such as Snapchat, which capitalise on content ephemerality to create brand relationships (Sashittal, DeMar, \& Jassawalla, 2016), and thus provide exciting opportunities to test levels of cognitive engagement and attention. Further research is warranted to explore the fascinating realm of consumer engagement in social media.

\section{Disclosure statement}

No potential conflict of interest was reported by the author.

\section{Notes on contributor}

Laurence Dessart is assistant professor in marketing at KEDGE Business School in France.

\section{References}

Algesheimer, R., Dholakia, U. M., \& Herrmann, A. (2005). The social influence of brand community: Evidence from European car clubs. Journal of Marketing, 69(3), 19-34. doi:10.1509/ jmkg.69.3.19.66363

Anderson, J. C., \& Gerbing, D. W. (1988). Structural equation modeling in practice: A review and recommended two-step approach. Psychological Bulletin, 103(3), 411-423. doi:10.1037//00332909.103.3.411 
Ashley, C., \& Tuten, T. (2015). Creative strategies in social media marketing: An exploratory study of branded social content and consumer engagement. Psychology \& Marketing, 32(1), 15-27. doi:10.1002/mar.20761

Bagozzi, R. P., \& Dholakia, U. M. (2006). Antecedents and purchase consequences of customer participation in small group brand communities. International Journal of Research in Marketing, 23(1), 45-61. doi:10.1016/j.jiresmar.2006.01.005

Bagozzi, R. P., \& Yi, Y. (1988). On the evaluation of structural equation models. Journal of the Academy of Marketing Science, 16(1), 74-94. doi:10.1007/bf02723327

Bagozzi, R. P., Yi, Y., \& Phillips, L. W. (1991). Assessing construct validity in organizational research. Administrative Science Quarterly, 36, 421-458. doi:10.2307/2393203

Blazevic, V., Wiertz, C., Cotte, J., De Ruyter, K., \& Keeling, D. I. (2014). GOSIP in cyberspace: Conceptualization and scale development for general online social interaction propensity. Journal of Interactive Marketing, 28(2), 87-100. doi:10.1016/j.intmar.2013.09.003

Bowden, J. L. H. (2009). The process of customer engagement: A conceptual framework. Journal of Marketing Theory and Practice, 17(1), 63-74. doi:10.2753/mtp1069-6679170105

Breidbach, C., Brodie, R., \& Hollebeek, L. (2014). Beyond virtuality: From engagement platforms to engagement ecosystems. Managing Service Quality, 24(6), 592-611. doi:10.1108/msq-08-2013-0158

Brodie, R. J., Hollebeek, L. D., Juric, B., \& Ilic, A. (2011). Customer engagement: Conceptual domain, fundamental propositions, and implications for research. Journal of Service Research, 14(3), 252271. doi:10.1177/1094670511411703

Brodie, R. J., Ilic, A., Juric, B., \& Hollebeek, L. (2013). Consumer engagement in a virtual brand community: An exploratory analysis. Journal of Business Research, 66(1), 105-114. doi:10.1016/j. jbusres.2011.07.029

Calder, B. J., Malthouse, E. C., \& Schaedel, U. (2009). An experimental study of the relationship between online engagement and advertising effectiveness. Journal of Interactive Marketing, 23 (4), 321-331. doi:10.1016/j.intmar.2009.07.002

Casaló, L. V., Flavián, C., \& Guinalíu, M. (2010). Determinants of the intention to participate in firmhosted online travel communities and effects on consumer behavioral intentions. Tourism Management, 31(6), 898-911. doi:10.1016/j.tourman.2010.04.007

Chaudhuri, A., \& Holbrook, M. B. (2001). The chain of effects from brand trust and brand affect to brand performance: The role of brand loyalty. Journal of Marketing, 65(2), 81-93. doi:10.1509/ jmkg.65.2.81.18255

Chaudhuri, A., \& Holbrook, M. B. (2002). Product-class effects on brand commitment and brand outcomes: The role of brand trust and brand affect. The Journal of Brand Management, 10(1), 3358. doi:10.1057/palgrave.bm. 2540100

de Villiers, R. (2015). Consumer brand enmeshment: Typography and complexity modeling of consumer brand engagement and brand loyalty enactments. Journal of Business Research, 68(9), 1953-1963. doi:10.1016/j.jbusres.2015.01.005

de Vries, L., Gensler, S., \& Leeflang, P. S. (2012). Popularity of brand posts on brand fan pages: An investigation of the effects of social media marketing. Journal of Interactive Marketing, 26(2), 8391. doi:10.1016/j.intmar.2012.01.003

Dessart, L., Veloutsou, C., \& Morgan-Thomas, A. (2015). Consumer engagement in online brand communities: A social media perspective. Journal of Product \& Brand Management, 24(1), 28-42. doi:10.1108/jpbm-06-2014-0635

Dessart, L., Veloutsou, C., \& Morgan-Thomas, A. (2016). Capturing consumer engagement: Duality, dimensionality and measurement. Journal of Marketing Management, 32(5-6), 399-426. doi:10.1080/0267257x.2015.1130738

Dholakia, U. M., Bagozzi, R. P., \& Pearo, L. K. (2004). A social influence model of consumer participation in network-and small-group-based virtual communities. International Journal of Research in Marketing, 21(3), 241-263. doi:10.1016/j.jiresmar.2003.12.004

Dolan, R., Conduit, J., Fahy, J., \& Goodman, S. (2016). Social media engagement behaviour: A uses and gratifications perspective. Journal of Strategic Marketing, 24(3-4), 261-277. doi:10.1080/ $0965254 X .2015 .1095222$ 
Dwivedi, A. (2015). A higher-order model of consumer brand engagement and its impact on loyalty intentions. Journal of Retailing and Consumer Services, 24, 100-109. doi:10.1016/j. jretconser.2015.02.007

El-Manstrly, D., \& Harrison, T. (2013). A critical examination of service loyalty measures. Journal of Marketing Management, 29(15-16), 1834-1861. doi:10.1080/0267257x.2013.803139

Forrester Research. (2014). Predictions 2015: Social media grows up: A stable social landscape will foster marketing, customer insights, and sales success. [Online]. Retrieved from https://www. forrester.com/Predictions+2015+Social+Media+Grows+Up/fulltext/-/E-RES119621?docid= 119621 andal $=0$

Fournier, S., \& Avery, J. (2011). The uninvited brand. Business Horizons, 54(3), 193-207. doi:10.1016/ j.bushor.2011.01.001

France, C., Merrilees, B., \& Miller, D. (2016). An integrated model of customer-brand engagement: Drivers and consequences. Journal of Brand Management, 23(2), 119-136. doi:10.1057/ bm.2016.4

Gambetti, R., \& Graffigna, G. (2010). The concept of engagement: A systematic analysis of the ongoing marketing debate. International Journal of Market Research, 52(6), 801-826. doi:10.2501/s147078531020166

Garbarino, E., \& Johnson, M. S. (1999). The different roles of satisfaction, trust, and commitment in customer relationships. Journal of Marketing, 63(2), 70-87. doi:10.2307/1251946

Geissinger, A., \& Laurell, C. (2016). User engagement in social media: An explorative study of Swedish fashion brands. Journal of Fashion Marketing and Management: An International Journal, 20(2), 177-190. doi:10.1108/jfmm-02-2015-0010

Hair, J., Bush, R., \& Ortinau, D. (2006). Marketing research within a changing environment (3rd ed.). New York, NY: McGraw-Hill/Irwin.

Hennig-Thurau, T., Malthouse, E. C., Friege, C., Gensler, S., Lobschat, L., Rangaswamy, A., \& Skiera, B. (2010). The impact of new media on customer relationships. Journal of Service Research, 13(3), 311-330. doi:10.1177/1094670510375460

Hofstede, G. 2014. Cultural tools: Country comparison [Online]. Retrieved 29 December 2014, from: http://geert-hofstede.com/countries.html.

Hollebeek, L. D. (2011a). Demystifying customer brand engagement: Exploring the loyalty nexus. Journal of Marketing Management, 27(7-8), 785-807. doi:10.1080/0267257x.2010.500132

Hollebeek, L. (2011b). Exploring customer brand engagement: Definition and themes. Journal of Strategic Marketing, 19(7), 555-573. doi:10.1080/0965254x.2011.599493

Hollebeek, L., \& Chen, T. (2014). Exploring positively-versus negatively-valenced brand engagement: A conceptual model. Journal of Product \& Brand Management, 23(1), 62-74. doi:10.1108/JPBM-06-2013-0332

Hollebeek, L. D., Conduit, J., \& Brodie, R. J. (2016). Strategic drivers, anticipated and unanticipated outcomes of customer engagement. Journal of Marketing Management, 32(5-6), 393-398. doi:10.1080/0267257x.2016.1144360

Hollebeek, L. D., Glynn, M. S., \& Brodie, R. J. (2014). Consumer brand engagement in social media: Conceptualization, scale development and validation. Journal of Interactive Marketing, 28(2), 149-165. doi:10.1016/j.intmar.2013.12.002

Hollenbeck, C. R., \& Kaikati, A. M. (2012). Consumers' use of brands to reflect their actual and ideal selves on Facebook. International Journal of Research in Marketing, 29(4), 395-405. doi:10.1016/j. ijresmar.2012.06.002

Jaakkola, E., \& Alexander, M. (2014). The role of customer engagement behavior in value cocreation a service system perspective. Journal of Service Research, 17(3), 247-261. doi:10.1177/ 1094670514529187

Jang, H., Olfman, L., Ko, I., Koh, J., \& Kim, K. (2008). The influence of on-line brand community characteristics on community commitment and brand loyalty. International Journal of Electronic Commerce, 12(3), 57-80. doi:10.2753/jec1086-4415120304

Kaplan, A. M., \& Haenlein, M. (2010). Users of the world, unite! The challenges and opportunities of social media. Business Horizons, 53(1), 59-68. doi:10.1016/j.bushor.2009.09.003 
Lastovicka, J. L., \& Gardner, D. (1979). Components of involvement. In J. C. Maloney \& B. Silverman (Eds.), Attitude research plays for high stakes (pp. 53-73). Chicago: American Marketing Association.

Laurent, G., \& Kapferer, J.-N. (1985). Measuring consumer involvement profiles. Journal of Marketing Research, 22(1), 41-53. doi:10.2307/3151549

Leckie, C., Nyadzayo, M. W., \& Johnson, L. W. (2016). Antecedents of consumer brand engagement and brand loyalty. Journal of Marketing Management, 32(5-6), 558-578. doi:10.1080/ 0267257x.2015.1131735

Lemon, K. N., \& Verhoef, P. C. (2016). Understanding customer experience throughout the customer journey. Journal of Marketing, 80(6), 69-96. doi:10.1509/jm.15.0420

Malhotra, A., Malhotra, C. K., \& See, A. (2012). How to create brand engagement on Facebook. MIT Sloan Management Review, 54(2), 18-20.

Malthouse, E. C., Calder, J. C., Kim, S. J., \& Vandenbosch, M. (2016). Evidence that user-generated content that produces engagement increases purchase behaviors. Journal of Marketing Management, 32(5-6), 427-444. doi:10.1080/0267257x.2016.1148066

Marbach, J., Lages, C. R., \& Nunan, D. (2016). Who are you and what do you value? Investigating the role of personality traits and customer-perceived value in online customer engagement. Journal of Marketing Management, 32(5-6), 502-525. doi:10.1080/0267257x.2015.1128472

Marzocchi, G., Morandin, G., \& Bergami, M. (2013). Brand communities: Loyal to the community or the brand? European Journal of Marketing, 47(1/2), 93-114. doi:10.1108/03090561311285475

Matzler, K., Pichler, E., Füller, J., \& Mooradian, T. A. (2011). Personality, person-brand fit, and brand community: An investigation of individuals, brands, and brand communities. Journal of Marketing Management, 27(9-10), 874-890. doi:10.1080/0267257x.2010.543634

Mollen, A., \& Wilson, H. (2010). Engagement, telepresence and interactivity in online consumer experience: Reconciling scholastic and managerial perspectives. Journal of Business Research, 63 (9-10), 919-925. doi:10.1016/j.jbusres.2009.05.014

Moorman, C., Zaltman, G., \& Deshpande, R. (1992). Relationships between providers and users of market research: The dynamics of trust within and between organizations. Journal of Marketing Research, 29(3), 314-328. doi:10.2307/3172742

Morgan, R. M., \& Hunt, S. D. (1994). The commitment-trust theory of relationship marketing. Journal of Marketing, 58(3), 20-38. doi:10.2307/1252308

MSI, Marketing Science Institute (2014), 2014-2016 Research priorities. Retrieved from http://www. msi.org/research/2014-2016-research-priorities/

Murphy, J., Hill, C. A., \& Dean, E. (2014). Social media, sociality, and survey research. In C. A. Hill, E. Dean, \& J. Murphy (eds), Social Media, Sociality, and Survey Research (1st ed., pp. 1-33). Hoboken, $\mathrm{NJ}$ J John Wiley and Sons, Inc.

Odin, Y., Odin, N., \& Valette-Florence, P. (2001). Conceptual and operational aspects of brand loyalty: An empirical investigation. Journal of Business Research, 53(2), 75-84. doi:10.1016/s01482963(99)00076-4

Patterson, A. (2012). Social-networkers of the world, unite and take over: A meta-introspective perspective on the Facebook brand. Journal of Business Research, 65(4), 527-534. doi:10.1016/j. jbusres.2011.02.032

Porter, C. E., \& Donthu, N. (2008). Cultivating trust and harvesting value in virtual communities. Management Science, 54(1), 113-128. doi:10.1287/mnsc.1070.0765

Ruvio, A., Shoham, A., \& Brencic, M. M. (2008). Consumers' need for uniqueness: Short-form scale development and cross-cultural validation. International Marketing Review, 25(1), 33-53. doi:10.1108/02651330810851872

Sashi, C. M. (2012). Customer engagement, buyer-seller relationships, and social media. Management Decision, 50(2), 253-272. doi:10.1108/02651330810851872

Sashittal, H. C., DeMar, M., \& Jassawalla, A. R. (2016). Building acquaintance brands via Snapchat for the college student market. Business Horizons, 59(2), 193-204. doi:10.1016/j.bushor.2015.11.004

Schau, H. J., Muñiz, A. M., Jr., \& Arnould, E. J. (2009). How brand community practices create value. Journal of Marketing, 73(5), 30-51. doi:10.1509/jmkg.73.5.30 
Schivinski, B., Christodoulides, G., \& Dabrowski, D. (2016). Measuring consumers' engagement with brand-related social-media content. Journal of Advertising Research, 56(1), 64-80. doi:10.2501/ JAR-2016-004

Social Bakers. 2014. Top 15 facebook brand pages by engagement rate [socialbakers pro] [online]. Retrieved 4 February 2015, from http://www.socialbakers.com/blog/370-top-15-facebookbrand-pages-by-engagement-rate-socialbakers-pro.

Solem, B. A. A., \& Pedersen, P. E. (2016). The effects of regulatory fit on customer brand engagement: An experimental study of service brand activities in social media. Journal of Marketing Management, 32(5-6), 445-468. doi:10.1080/0267257x.2016.1145723

Sprott, D., Czellar, S., \& Spangenberg, E. (2009). The importance of a general measure of brand engagement on market behavior: Development and validation of a scale. Journal of Marketing Research, 46(1), 92-104. doi:10.1509/jmkr.46.1.92

Statista. (2016). Global social networks ranked by number of users 2016. [Online]. Retrieved from http://www.statista.com/statistics/278414/number-of-worldwide-social-network-users/

van Doorn, J., Lemon, K. N., Mittal, V., Nass, S., Pick, D., Pirner, P., \& Verhoef, P. C. (2010). Customer engagement behavior: Theoretical foundations and research directions. Journal of Service Research, 13(3), 253-266. doi:10.1177/1094670510375599

Verhoef, P. C., Reinartz, W. J., \& Krafft, M. (2010). Customer engagement as a new perspective in customer management. Journal of Service Research, 13(3), 247-252. doi:10.1177/ 1094670510375461

Vivek, S. D., Beatty, S. E., Dalela, V., \& Morgan, R. M. (2014). A generalized multidimensional scale for measuring customer engagement. Journal of Marketing Theory and Practice, 22(4), 401-420. doi:10.2753/MTP1069-6679220404

Vivek, S. D., Beatty, S. E., \& Morgan, R. M. (2012). Customer engagement: Exploring customer relationships beyond purchase. Journal of Marketing Theory and Practice, 20(2), 122-146. doi:10.2753/mtp1069-6679200201

Wiertz, C., \& De Ruyter, K. (2007). Beyond the call of duty: Why customers contribute to firm-hosted commercial online communities. Organization Studies, 28(3), 347-376. doi:10.1177/ 0170840607076003

Wirtz, J., Den Ambtman, A., Bloemer, J., Horváth, C., Ramaseshan, B., van de Klundert, J., \& Kandampully, J. (2013). Managing brands and customer engagement in online brand communities. Journal of Service Management, 24(3), 223-244. doi:10.1108/09564231311326978

Wu, L., \& Chen, J. L. (2005). An extension of trust and TAM model with TPB in the initial adoption of on-line tax: An empirical study. International Journal of Human-Computer Studies, 62(6), 784-808. doi:10.1016/j.ijhcs.2005.03.003

Yang, S., Lin, S., Carlson, J. R., \& Ross, W. T., Jr. (2016). Brand engagement on social media: Will firms' social media efforts influence search engine advertising effectiveness? Journal of Marketing Management, 32(5-6), 526-557. doi:10.1080/0267257x.2016.1143863

Zaglia, M. E. (2013). Brand communities embedded in social networks. Journal of Business Research, 66(2), 216-223. doi:10.1016/j.jbusres.2012.07.015 


\section{Appendix 1. Overview of antecedents and outcomes of consumer engagement}

\begin{tabular}{|c|c|c|c|c|c|}
\hline Authors & Paper type & $\begin{array}{c}\text { Engagement } \\
\text { object }\end{array}$ & Context & Construct & $\begin{array}{l}\text { Antecedent/ } \\
\text { outcome }\end{array}$ \\
\hline Bowden (2009) & Conceptual & Brand & Offline & Loyalty & 0 \\
\hline \multirow{5}{*}{$\begin{array}{l}\text { Sprott et al. } \\
\text { (2009) }\end{array}$} & \multirow[t]{5}{*}{ Empirical } & \multirow[t]{5}{*}{ Brand } & \multirow[t]{5}{*}{ Offline } & Involvement & $A$ \\
\hline & & & & Self-brand memory links & 0 \\
\hline & & & & Brand recall & 0 \\
\hline & & & & Brand attention & 0 \\
\hline & & & & Product preference & 0 \\
\hline \multirow{7}{*}{$\begin{array}{l}\text { Van Doorn et al. } \\
\qquad(2010)\end{array}$} & \multirow[t]{7}{*}{ Conceptual } & \multirow[t]{7}{*}{ Brand } & \multirow[t]{7}{*}{ Offline } & Identity & $A$ \\
\hline & & & & Consumption goals & $A$ \\
\hline & & & & Resources & $A$ \\
\hline & & & & Perceived costs/benefits & $A$ \\
\hline & & & & Trust & $A$ \\
\hline & & & & Commitment & $A$ \\
\hline & & & & Satisfaction & $A$ \\
\hline \multirow{4}{*}{$\begin{array}{l}\text { Mollen and } \\
\text { Wilson (2010) }\end{array}$} & \multirow[t]{4}{*}{ Conceptual } & \multirow[t]{4}{*}{ Brand } & \multirow[t]{4}{*}{ Online } & Flow & $A$ \\
\hline & & & & Interactivity & $A$ \\
\hline & & & & Telepresence & $A$ \\
\hline & & & & $\begin{array}{l}\text { Optimal consumer } \\
\text { attitudes and } \\
\text { behaviours }\end{array}$ & 0 \\
\hline \multirow{3}{*}{$\begin{array}{l}\text { Brodie et al. } \\
\qquad(2011)\end{array}$} & \multirow[t]{3}{*}{ Conceptual } & \multirow[t]{3}{*}{ Brand } & \multirow{3}{*}{$\begin{array}{l}\text { Offline and } \\
\text { online } \\
\text { (service } \\
\text { brands) }\end{array}$} & Trust & $A$ \\
\hline & & & & Commitment & $A$ \\
\hline & & & & Satisfaction & $A \& 0$ \\
\hline $\begin{array}{r}\text { Hollebeek } \\
(2011 a)\end{array}$ & Conceptual & Brand & Offline & Flow & $A$ \\
\hline \multirow{9}{*}{$\begin{array}{r}\text { Hollebeek } \\
(2011 b)\end{array}$} & \multirow[t]{9}{*}{ Conceptual } & \multirow[t]{9}{*}{ Brand } & \multirow[t]{9}{*}{ Offline } & Involvement & $A$ \\
\hline & & & & Interactivity & $A$ \\
\hline & & & & Rapport & $A$ \\
\hline & & & & Trust & $A \& 0$ \\
\hline & & & & Commitment & $A \& 0$ \\
\hline & & & & Satisfaction & $A \& 0$ \\
\hline & & & & Loyalty & $A \& 0$ \\
\hline & & & & Co-created value & 0 \\
\hline & & & & Experience & 0 \\
\hline \multirow{3}{*}{$\begin{array}{l}\text { Vivek et al. } \\
\quad(2012)\end{array}$} & \multirow[t]{3}{*}{ Conceptual } & \multirow{3}{*}{$\begin{array}{l}\text { Organisational } \\
\text { offering or } \\
\text { activities }\end{array}$} & Offline & Involvement & $A$ \\
\hline & & & & Participation & $A$ \\
\hline & & & & WOM & 0 \\
\hline Brodie et al. & Empirical & Brand and/or & Online brand & Trust & 0 \\
\hline (2013) & (qualitative) & community & community & Commitment & 0 \\
\hline & & members & (blog) & Satisfaction & 0 \\
\hline & & & & Empowerment & 0 \\
\hline & & & & $\begin{array}{l}\text { Connection and } \\
\text { emotional bond }\end{array}$ & 0 \\
\hline & & & & Loyalty & 0 \\
\hline & & & & $\begin{array}{l}\text { Need to reduce } \\
\text { information search } \\
\text { and perceived risk }\end{array}$ & $A$ \\
\hline Hollebeek et al. & Empirical & Brand & Social media & Involvement & $A$ \\
\hline (2014) & & & brands & Self-brand connection & 0 \\
\hline & & & & Brand usage intent & 0 \\
\hline Dwivedi (2015) & Empirical & Brand & Offline & $\begin{array}{l}\text { Involvement with } \\
\text { category }\end{array}$ & $A$ \\
\hline & & & & Loyalty intentions & 0 \\
\hline
\end{tabular}


(Continued).

\begin{tabular}{|c|c|c|c|c|c|}
\hline Authors & Paper type & $\begin{array}{c}\text { Engagement } \\
\text { object }\end{array}$ & Context & Construct & $\begin{array}{l}\text { Antecedent/ } \\
\text { outcome }\end{array}$ \\
\hline $\begin{array}{l}\text { France et al. } \\
\qquad(2016)\end{array}$ & Empirical & Brand & Offline & $\begin{array}{l}\text { Brand interactivity } \\
\text { Brand quality } \\
\text { Brand-self congruity } \\
\text { Brand involvement } \\
\text { Brand value } \\
\text { Brand loyalty }\end{array}$ & $\begin{array}{l}A \\
A \\
A \\
A \\
O \\
O\end{array}$ \\
\hline $\begin{array}{l}\text { Solem and } \\
\text { Pedersen } \\
(2016)\end{array}$ & Empirical & Brand & $\begin{array}{c}\text { Social media - } \\
\text { Facebook }\end{array}$ & Regulatory fit & $A$ \\
\hline $\begin{array}{l}\text { Malthouse et al. } \\
\text { (2016) }\end{array}$ & Empirical & Brand & Social media & Buying decisions & 0 \\
\hline $\begin{array}{l}\text { Marbach et al. } \\
(2016)\end{array}$ & $\begin{array}{l}\text { Empirical, } \\
\text { qualitative }\end{array}$ & Brand & Social media & Personality traits & $A$ \\
\hline $\begin{array}{l}\text { Yang, Lin, } \\
\text { Carlson, and } \\
\text { Ross (2016) }\end{array}$ & Empirical & Brand & Online & $\begin{array}{l}\text { Search engine } \\
\text { advertising } \\
\text { effectiveness }\end{array}$ & 0 \\
\hline $\begin{array}{l}\text { Leckie, } \\
\text { Nyadzayo, and } \\
\text { Johnson } \\
(2016)\end{array}$ & Empirical & Brand & Offline & $\begin{array}{l}\text { Involvement } \\
\text { Participation } \\
\text { Self-expressive brand }\end{array}$ & $\begin{array}{l}A \\
A \\
A\end{array}$ \\
\hline
\end{tabular}

\section{Appendix 2. Items}

Online interaction propensity (Wiertz \& De Ruyter, 2007)

In general, I like to get involved in online discussions

I am someone who enjoys interacting with like-minded people online

I am someone who likes actively participating in online discussions

In general, I thoroughly enjoy exchanging ideas with others online

Attitude toward community participation (Bagozzi \& Dholakia, 2006)

On the following scales, please express your attitude toward participating in the group (semantic differential)

- Foolish/Wise

- Harmful/Beneficial

- Bad/Good

- Punishing/Rewarding

Product involvement (Laurent \& Kapferer, 1985)

This type of product is very important to me

This type of product matters to me

When you buy this type of product, it's a big deal if you make a mistake

I particularly like this type of product

You can really tell a lot about a person by the type of product he/she picks out

Social media engagement (Dessart et al., 2016)

The items below were administered twice, one with respect to the brand, and once to the community as evidenced by the (brand/community) placeholder.

Affective engagement

I feel enthusiastic about (brand/community)

I am interested in anything about (brand/community)

I find (brand/community) interesting

When interacting with (brand/community), I feel happy

I get pleasure from interacting with (brand/community) 
Interacting with (brand/community) is like a treat for me

Cognitive engagement

I spend a lot of time thinking about (brand/community)

I make time to think about (brand/community)

When interacting with (brand/community), I forget everything else around me

Time flies when I am interacting with (brand/community)

When I am interacting with (brand/community), I get carried away

When interacting with (brand/community), it is difficult to detach myself

Behavioural engagement

I share my ideas with (brand/community)

I share interesting content with (brand/community)

I help (brand/community)

I ask (brand/community) questions

I seek ideas or information from (brand/community)

I seek help from (brand/community)

I promote (brand/community)

I try to get other interested in (brand/community)

I actively defend (brand/community) from its critics

I say positive things about (brand/community) to other people

Brand trust (Chaudhuri and Holbrook, 2001)

I trust this brand

I rely on this brand

This is an honest brand

This brand is safe

Brand commitment (El-Manstrly \& Harrison, 2013)

I have grown to like this brand more than others offering the same product/service

I like the product/services offered by this brand

To me, this brand is the one whose product/services I enjoy using most

Brand loyalty (Odin et al., 2001)

I am loyal to only one brand (the one I follow), when I buy this type of product

For my next purchase, I will buy this brand again

I always buy this brand

I usually buy this brand 


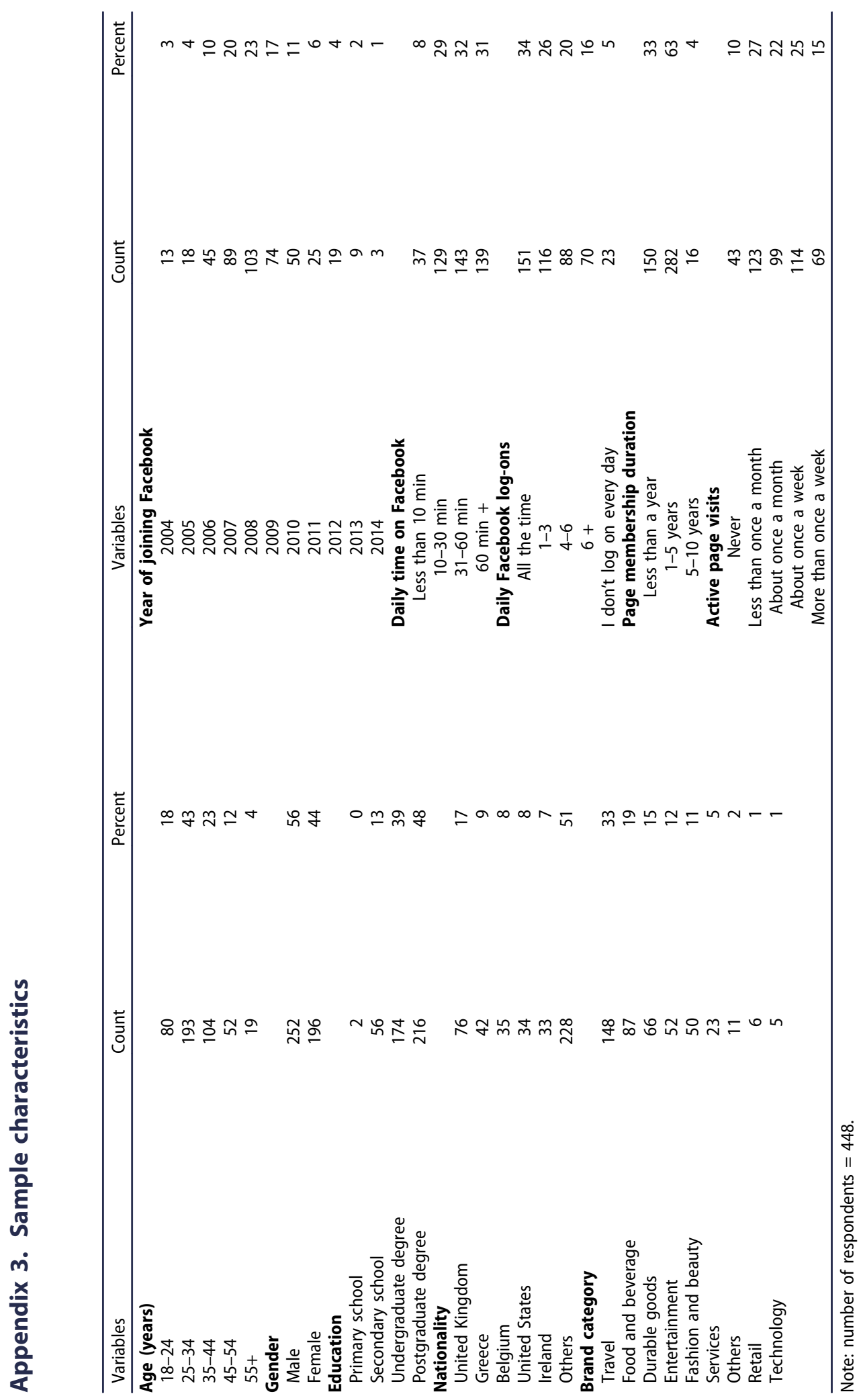




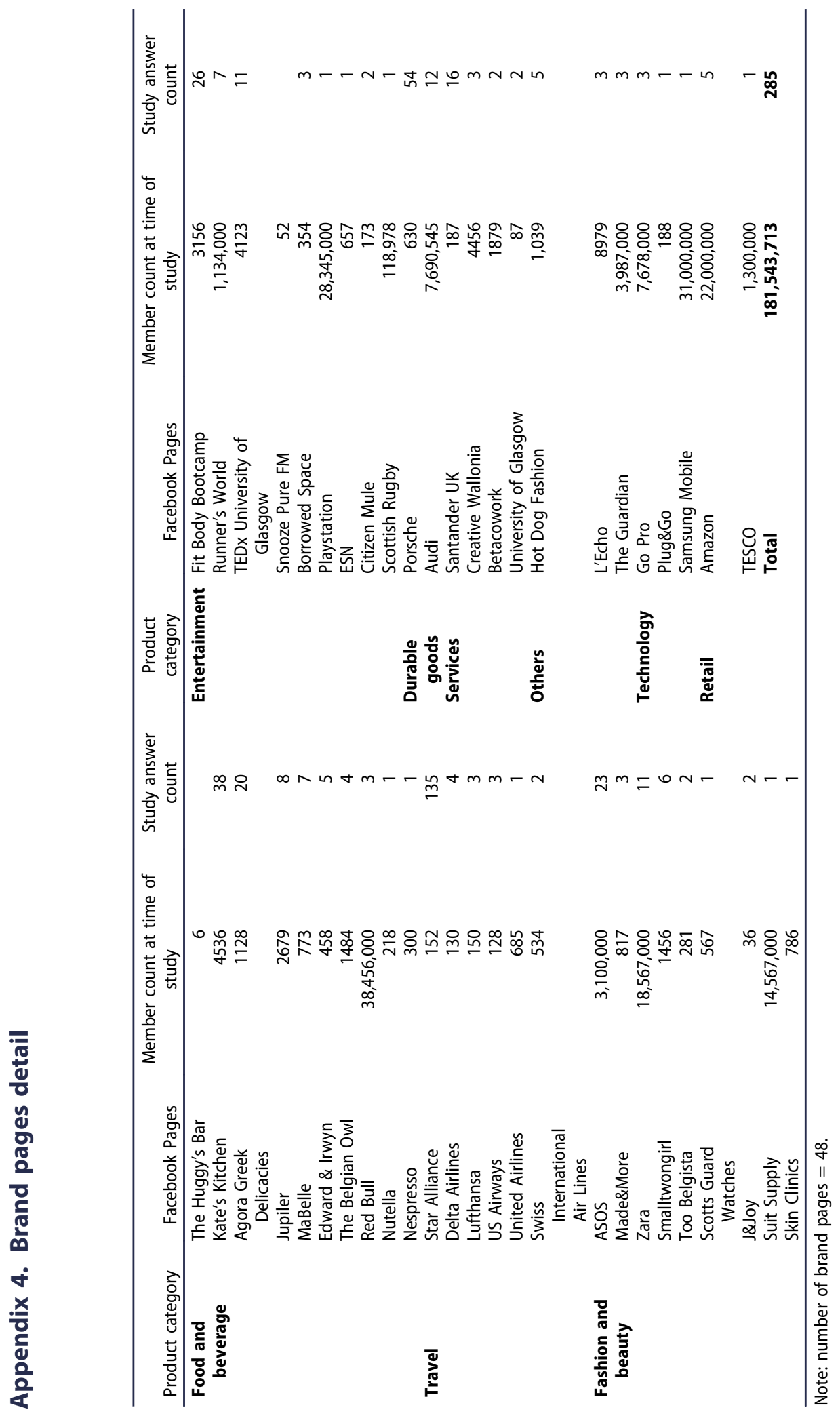

